\title{
What sells in a crisis? Determinants of sale probability over a cycle and through a crash
}

Article

Accepted Version

Scofield, D. and Devaney, S. (2017) What sells in a crisis? Determinants of sale probability over a cycle and through a crash. Journal of Property Investment \& Finance, 35 (6). pp. 619-637. ISSN 1463-578X doi: https://doi.org/10.1108/JPIF02-2017-0013 Available at https://centaur.reading.ac.uk/72880/

It is advisable to refer to the publisher's version if you intend to cite from the work. See Guidance on citing.

To link to this article DOI: http://dx.doi.org/10.1108/JPIF-02-2017-0013

Publisher: Emerald Group Publishing Limited

All outputs in CentAUR are protected by Intellectual Property Rights law, including copyright law. Copyright and IPR is retained by the creators or other copyright holders. Terms and conditions for use of this material are defined in the End User Agreement.

www.reading.ac.uk/centaur 
Central Archive at the University of Reading

Reading's research outputs online 


\section{What sells in a crisis? Determinants of sale probability over a cycle and through a crash}

\begin{tabular}{|r|l|}
\hline Journal: & Journal of Property Investment \& Finance \\
\hline Manuscript ID & JPIF-02-2017-0013.R1 \\
\hline Manuscript Type: & Academic Paper \\
\hline Keywords: & $\begin{array}{l}\text { liquidity, ownership, sale probability, market cycles, turnover, foreign } \\
\text { investment }\end{array}$ \\
\hline \multicolumn{2}{|c}{} \\
\hline
\end{tabular}

\section{SCHOLARONE ${ }^{\text {w }}$ \\ Manuscripts}




\section{What sells in a crisis? Determinants of sale probability over a cycle and through a crash}

\section{INTRODUCTION}

Real estate assets are lumpy and heterogeneous, and their returns vary based on their physical and spatial characteristics. Investors in commercial real estate exchange rights to properties in private, decentralized markets and through a process that is often lengthy and involves significant transaction costs. These factors reduce liquidity in real estate as compared with many other investment assets. In this paper, we try to understand what affects the liquidity of individual commercial real estate assets over the course of the economic cycle, focusing on the probability of sale as a proxy for liquidity. Identifying and analyzing the variables that affect likelihood of sale during different market periods can inform investment strategy and is important for understanding real estate market conditions. Our study explores a range of variables and a number of time periods in order to identify key determinants of sale probability and how these change over time. The results provide insights into investment behavior over a commercial real estate cycle.

In previous work, Fisher et al. (2004) examined the probability of a commercial real estate sale as a function of market, property and owner characteristics, finding that each group of factors displayed roughly equal significance to sale probability. A similar array of factors is studied here. However, while their US dataset reflected the activity of domestic institutional investors, our UK dataset includes both institutional and non-institutional real estate investors, as well as domestic and foreign investors. We also extend previous analysis by splitting our time period into subperiods that correspond with different phases of the commercial real estate cycle. We explore the effects of factors such as real estate price movements, economic growth and changes in the flow and cost of funds, in addition to property related attributes such as sector, size and location. Meanwhile, the presence of ownership variables in our dataset enables us to study the influence 
of (equity) ownership type and nationality on the probability of sale. These additions represent significant advances on previous research.

We find that the types of properties that are most likely to sell change between strong and weak markets. For example, office and retail assets were more likely to sell than industrial ones both overall and in better market conditions, but they were less likely to sell than industrial properties during the downturn from mid-2007 to mid-2009. However, other factors were more enduring in increasing the probability of sale, with assets located in the City of London more likely to sell in both strong and weak markets. Meanwhile, the behavior of different groups of owners changed over time. Nonetheless, private investors, REITs and REOCs were more active than institutions, while European owners were less active than domestic owners. This indicates that the type of owner might have implications for the liquidity of individual assets over and above their physical and locational attributes.

This study marks the first time that research has sought to determine likelihood of sale across different property and investor types (including foreign and domestic) at different points in the market cycle. This matters as it is during periods of market instability that liquidity is arguably most important. Understanding which assets are most likely to trade at such times is informative to investors in general, but of particular interest to types of investors whose need to maintain or access capital in such markets is greatest. For instance, Forbes (2017) suggests that selection of properties by UK open-ended funds is influenced by their perceived saleability in the event of high redemption requests. Investor sensitivity to liquidity shocks will affect the types of investors and types of stock that sell in different phases of the real estate cycle. This has knock on effects for the availability and interpretation of market evidence at different times in tasks like appraisal and market analysis. 
In order to determine what sells and who sells investment grade commercial real estate prior to, during and following a period of acute financial crisis, we examine data obtained from Real Capital Analytics/Property Data (RCA/PD) on over 12,000 transactions in the UK commercial real estate market between 2001 and 2013. We model probability of sale in this market for the period $2003 \mathrm{H} 2$ to $2013 \mathrm{H} 1$, examining the whole period and five sub-periods which capture distinct market states. The rest of the paper proceeds as follows. The next section discusses previous research on sale probability and related research on holding periods. The following section then details the data that are used and the modelling approach. After this, our empirical results are presented. The paper then concludes with a discussion of the importance and ramifications of the findings.

\section{BACKGROUND AND REVIEW}

Transaction volume, turnover and the probability that a particular asset will trade are interrelated measures of transaction activity that are connected to the concept of liquidity. Different proxies capture different dimensions of liquidity and these include measures of activity and measures of how quickly assets are selling. Together, such measures provide information on liquidity and real estate market conditions (for a review of liquidity measures, see Ametefe et al. 2016). The focus of this work is on the probability of sale, but, to illustrate how different measures of activity are related, we adapt a stylized example from Fisher et al. (2004). Say a particular location has a stock of 1,200 properties and that 120 of those properties are sold each year, each being the subject of a separate transaction. The proportion of assets traded - or turnover - would be $10 \%$ and, if each property was similar and had an equal chance of being sold, then the probability that any one asset would sell in that period is $10 \%$. The average holding period in this scenario would be 10 years. 
However, in reality, the heterogeneity of properties affects not only their potential price, but also their attractiveness to different buyers and sellers. In turn, this creates differences in how likely it is that particular assets will trade, as well as how long it will take to sell them once marketed for sale. This could be down to attributes that are positive or negative: for example, a new and well located asset might have a greater number of potential buyers, yet the owners may be less willing to sell because of these features (Collett et al. 2003). Furthermore, even where two buildings are similar, attributes of the owners may play a role in how likely it is that they will sell. Therefore, to understand better which factors might be relevant, we consider previous studies that have examined likelihood of sale as well as related work on factors that influence holding periods.

Using transactions from the National Council of Real Estate Investment Fiduciaries (NCREIF) database from Q1 1978 to Q4 1986, Guilkey et al. (1989) compared 277 sold with 192 unsold commercial properties. The NCREIF database focuses on private real estate investments in the US held by US institutional investors. As well as building attributes, Guilkey et al. tested macroeconomic and socio-demographic variables, including trends in construction, manufacturing and wholesale earnings, to determine what factors influenced disposals. Although their samples of sold and unsold assets were small, they found that managers were more likely to sell buildings that were smaller and less accessible, and which provided them with the least compensation relative to costs. Moreover, sales were found to be pro-cyclical, with assets more likely to sell in markets characterized by strong demand and rising levels of new supply.

Fisher et al. (2004) also examined the determinants of sale probability, linking this concept with transaction frequency, in US commercial real estate markets. They provide a framework that is applied and developed in this paper. Their work defines the likelihood of a sale as the product of market, property and owner characteristics. Market price movements and transaction frequency 
correspond with the relative number of buyers and sellers in the market. The study argues that periodic changes in transaction frequency are the result of relative changes in buyer and seller reservation price distributions; greater overlap should equate to higher transaction volumes and more liquidity. They then empirically test their ideas using the NCREIF database, comparing the attributes of 1,556 sold properties with 16,876 unsold assets through time.

Fisher et al. (2004) outline three groups of factors that impact the probability of sale and the frequency of transactions. First, market conditions affect sale probability. This includes aspects of the wider economic environment such as the flow and cost of funds, and portfolio effects as returns from competing assets prompt portfolio rebalancing. Government legislation, including the impact of regulation and taxation, can also have a significant impact on transaction volumes. Second, ownership factors are found to be important, including organization type (open-ended or closed-end fund), use of leverage and sale strategy (opportunistic or sell winners). Third, property factors such as age and total square footage were positively related to sale probability. The authors concluded that market, ownership and property specific factors "play significant, independent and approximately equivalent roles in determining transaction frequency" (p. 263). While this is important research in this area, the authors were limited by their dataset to analysis of institutional investor behaviour only. This paper broadens the scope of previous analysis by including a comprehensive sample of owner types, including non-institutional and non-domestic investors.

Related research on repeat sales is provided by Chinloy et al. (2013) using data on multi-family assets sold in Los Angeles and Chicago (1998-2011). They find that frequently traded assets are of a different character to the rest and so they regard more frequently transacted properties as representing a different property population. Specifically, properties that provide the investor with an opportunity to add value through refurbishment transact more regularly, at lower-than- 
average prices on initial sale and at higher-than-average prices on repeat sale. The authors identify government policy in the US regarding taxation as having a significant impact as well, noting that REITs were less likely to reposition when capital gains comprised more than $25 \%$ of a trust's income and tax exemptions disappeared. While the effects of government policies are not tested in this study, the impact of policy in terms of bond rates, for example, are captured. However, we do not examine multi-family properties as this particular sector did not normally appear in UK commercial real estate investment portfolios during the period covered by this research.

Chinloy et al. (2013) also observe that price or return indices which rely on frequently traded assets may be influenced by the specific nature of those assets and transactions. Furthermore, Gatzlaff and Haurin (1998) show that even performance measures that use all available sales can be affected by sample selection biases. The issue is whether prices for the properties that do trade provide signals that are representative for the wider population of assets. The first step in understanding this is to establish whether the sample of properties that do trade exhibit some systematic differences from the set of properties that do not trade, and whether such differences persist through time or are particularly important at different points in the real estate cycle.

Guilkey et al. (1989) assessed the implications of sample selectivity for price index estimation and concluded that, to control for possible biases when using transaction data, joint estimations of sale price and sale probability were necessary. Fisher et al. (2003) and Fisher et al. (2007) pursued a two-step approach where a model of sale probability provided output that was then used in the modelling of commercial real estate prices. The first of these two studies suggested that controlling for sample selection had an important impact on index results, while the second suggested that the impact of selection bias was not significant. Devaney and Martinez Diaz (2011) explored how sample selection effects vary through time, showing that bias impacted on 
index results for the UK in 22 out of 34 quarters in their sample period. However, neither this study nor Fisher et al. (2007) explored the factors affecting sale probability in depth, but instead they focused on index estimation. ${ }^{[i]}$

Gau and Wang (1994) examined factors that impact the length of time that investors hold real estate. If particular factors are found to encourage shorter (longer) holding periods, then those same factors will drive more (less) trading as a consequence. 1,031 office, retail and apartment transactions in Vancouver between 1971 and 1985 were studied. With taxation as their focus, Gau and Wang found that holding periods were more affected by investors' non-tax preferences and changes in mortgage interest rates than by tax legislation. Meanwhile, Fisher and Young (2000) considered holding periods for real estate owned by tax-exempt institutional investors in the US. They analyzed over 6,500 sold and unsold assets in the NCREIF database over 19801998. The median holding period was found to be 11 years, with a shorter holding period for apartment properties. They also found that holding periods were affected by market conditions, observing a positive correlation between turnover within NCREIF and investment returns.

Collett et al. (2003) examined holding periods for institutional investors in the UK using the IPD database of private property investments. The average holding period of 12 years for properties bought in the 1980s was similar to the average found by Fisher and Young (2000). Collett et al. found that holding periods varied over the market cycle and by property type. Large properties were less likely to sell, while asset returns and elapsed time since purchase also influenced the propensity to be traded. Finally, Brown and Geurts (2005) explored holding periods for San Diego apartment buildings over a 21 year period. They found that investors were more likely to sell when the value of the property was rising faster than rents. 
Related research has attempted to model the optimal holding period for real estate investments. Baroni et al. (2007) identify the interaction between capital growth and rental income over time as key for modelling optimal holding period in commercial real estate. Cheng et al. (2010) also model optimal holding period using the NCREIF Index. They note a trade-off between high transaction costs and the risk of variable marketing periods versus a greater degree of pricerelated uncertainty as holding periods lengthen. The authors reflect on how asset and owner characteristics might influence holding periods from a theoretical perspective. For instance, they discuss how optimal holding periods should vary between investors with different degrees of risk aversion.

Our study differs from the existing literature in several ways. First, we include transactions that involve all investor types and do not limit our analysis to institutional investors, unlike Fisher et al. (2004) or Collett et al. (2003). This is important as sales by institutional investors comprised less than half of the sales occurring in the UK market over the period of this study. Moreover, our dataset contains information on country of origin for buyers and sellers, which allows us to explore the influence of foreign ownership on the probability of sale, a factor not included in previous research. We also look at transactions in five distinct periods that correspond with different phases of the UK commercial real estate cycle (growth, boom, downturn, recovery and growth) to understand the factors that most significantly affected sales at key points during the cycle, including the period comprising the Global Financial Crisis (GFC).

\footnotetext{
A key objective of this paper is to understand how the composition of buyers and sellers varies during different market states. Studies suggest that the marginal buyer for different types and grades of property might vary, and that this is important for investors as this can influence which assets are more likely to trade. However, guided by previous research, we postulate that market variables, property type and location will impact the probability of sale as well. For instance, we
} 
anticipate that shocks to the global financial system might affect real estate investment in the financial centre of London differently to that in other UK locations (see Lizieri and Pain, 2014). Meanwhile, in terms of market-wide influences, weaker economic growth, increased perceptions of risk and reductions in the flow of debt are all expected to dampen investment and reduce sale probability.

Furthermore, we expect that higher quality assets will be more liquid over the cycle. However, whether or not this translates into a higher probability of sale is unclear owing to the distinction between transaction frequency and liquidity. For example, while higher quality assets are often perceived as more saleable, the characteristics that make them more saleable might prompt their owners to retain them longer (Collett et al. 2003). During periods of market instability, many owners will hold assets until prices have stabilized, but some will be required to raise capital in order to meet debt repayments or, in the case of open ended funds, redemptions by investors. In these circumstances, we expect that only the best, most saleable assets will trade. Thus, we expect there to be more selection bias in times of market stress and that the dimensions of selection bias will reflect quality either in terms of asset attributes or location.

\section{DATA AND METHODS}

For our study, we use data on UK commercial real estate transactions provided by Real Capital Analytics (RCA). RCA is a research company that tracks transactions of commercial real estate above a threshold of $\$ 10$ million for all major markets around the world. In the UK, RCA works in partnership with Property Data (PD), a UK-based company, and they collect data on many deals below the $\$ 10$ million threshold as well. Information on transactions is obtained from multiple sources including brokerage and investment firms, listing services, press reports and public records. ${ }^{[i i]}$ We use the RCA/PD database to test which factors affect the probability of sale for 
different properties and whether these factors change at different points in the commercial real estate cycle.

The dataset we used spanned the period 2001 Q1 to 2013 Q1, which included a major commercial real estate boom and a subsequent collapse in values with the onset of the GFC. Figure 1 shows the RCA/PD UK Commercial Property Price Index (CPPI) for the majority of this period as well as the total volume of transactions recorded by RCA/PD. Prices rose by more than $60 \%$ from the start of the index (which begins in 2002 Q4) through to the peak in the market in 2007 Q2, before falling by more than $40 \%$ from the peak to the bottom of the market in 2009 Q2. Trading was markedly pro-cyclical in this period, with a clear correlation between volumes and price growth.

\section{Figure 1}

Before analysing the dataset, we removed transactions relating to development land, and sales of apartments and hotels, which are not significant sectors for real estate investment in the UK. This left us with industrial, office and retail assets. We removed some, but not all, portfolio transactions. In cases where the properties in a portfolio deal were individually identified, we kept the records on the grounds that they retained relevance for understanding which buildings were selected for sale over time. If details of the constituent assets were unavailable, then we removed the portfolio transaction from our dataset. ${ }^{[i i]}$ Finally, in common with other studies, we removed 'flips', defined as assets bought and then sold again inside twelve months.

This left 12,109 transactions of which 2,710 observations were repeat sales. This means that the dataset contains records of 9,399 individual assets. Table I shows the number of observations by sector and location. Offices are the largest sector by both number and value of 
deals, followed by retail and industrial. Geographically, the sample is spread across the UK, but a large proportion of deals relate to Central London. The data are weighted more heavily to offices and to London than the data on which the IPD UK property index is estimated. However, the latter is based on the portfolios of domestic investors only while the RCA/PD data allows us to observe both domestic and foreign investor activity. Our dataset mirrors more closely recent estimates of the structure of the UK real estate investment market made by Mitchell (2015).

Table I also reports the type and nationality of seller in each case. Type of organisation is based on categories used by RCA/PD. ${ }^{[i v] ~ I n s t i t u t i o n s ~ i n c l u d e ~ i n s u r a n c e ~ c o m p a n i e s ~ a n d ~ p e n s i o n ~ f u n d s, ~}$ while third-party manager refers to investment management companies that manage private real estate investments on behalf of other organizations. In these cases, typically, the end-client is not recorded. REITs and REOCs refer to listed real estate companies while 'private' includes non-listed real estate companies and individuals. There were some instances where the type of seller was unknown and these cases have been excluded from the econometric analysis that follows. ${ }^{[v]}$

\section{Table I}

Figures 2 and 3 show how often different investor types acted as either buyer or seller during the period and how the mix has shifted over time. Institutions and third party managers took part in a smaller proportion of purchases and a larger proportion of sales during the GFC. We believe there are at least two factors behind this. First, some institutions faced severe capital restraints during the downturn that necessitated sale of real estate assets to offset asset value impairments and maintain capital requirements. Another factor that drove sales was redemption requests from retail investors in UK open-ended real estate funds (Crosby et al. 2010). A shift in investment preferences away from real estate towards lower risk and more liquid investments 
will have had a significant impact on the behaviour of institutions during the GFC. There is also a notable increase in the share of sales involving REITs or REOCs during 2009, the reasons for which are less clear.

\section{Figure 2}

Figure 3

For nationality, individual countries are identified in the dataset, but four groups were used in this analysis after testing a number of alternatives. The nationality groups were UK (domestic) investors, European investors, US investors and investors from other nations. UK investors were the largest group in terms of sellers and buyers, but their importance varied across submarkets, with them constituting only $58 \%$ of sellers and $48 \%$ of buyers in the City of London and $60 \%$ of sellers and $52 \%$ of buyers in the West End of London. Increasing foreign ownership of commercial real estate in London has been noted in several studies including Lizieri et al. (2011) and Mitchell (2015). As with investor type, there are some cases where nationality is not known and these cases are also excluded from the econometric analysis that follows.

Tracking nationality is not straightforward. The growth of private investment funds together with the internationalization of real estate investment mean that while the registered office of a buyer or seller might be easy to identify, the location of effective or beneficial ownership may be different and hard to observe (see Lizieri et al. 2011). Moreover, the use of joint ventures meant that there were numerous cases where more than one buyer or seller was recorded. This raises questions of how to classify ownership when multiple types or nationalities are involved. In the absence of more extensive information about the parties involved, we acknowledge these issues, but follow the decisions made by RCA/PD in regard to the choice of type and nationality 
for their statistics on capital flows. This represents a limitation to our analysis, but we consider this to be unavoidable if we are to include information about ownership in our models.

An issue in studying probability of sale using a transactions dataset is that we do not observe directly the properties that do not sell. Without a building-by-building inventory of the commercial real estate stock, we utilise an innovative approach to generate a sample of held assets in each period. Splitting the study period into twelve-month intervals, we identify the assets that sold in each interval and a pool of unsold properties constructed from the records for buildings which traded outside that interval. The twelve month intervals are not based on calendar years, but run from end of June in one year to end of June in the next year. This reflects that key turning points in the UK commercial real estate cycle, illustrated by Figure 1, occurred in mid-2007 and mid2009, not at calendar year ends. We also use these intervals to define sub-periods, which we discuss below.

Identifying the sold and unsold assets in each interval might seem straightforward, but the process is complicated by the occurrence of repeat sales. These necessitate the use of controls to ensure that each asset is represented only once within each interval, either as a sale or in the unsold set. When a property is sold, any other records that relate to that asset (e.g. records of future sales) are dropped from the dataset for that interval. For unsold properties, any that have more than one record are identified and the most recent record prior to the interval concerned is used to represent it. However, if all sales occur in periods after the interval in question, then the earliest available record is used. For example, if a property sells in 2004, 2007 and 2012, the unsold samples for 2001-3 would use the 2004 record with the seller as owner, those for 2005-6 would use the 2004 record with the buyer as owner, and the samples for 2008-13 would use the 2007 record with the next buyer as the owner to represent it in the unsold group. 
This procedure is akin to a perpetual inventory approach. While it cannot capture the entire stock in the industrial, office and retail sectors, it does provide a large sample of non-traded assets in each period to allow variations in trading preferences over time to be identified. We proceed to test for the presence of such variations in the following manner. As in Fisher et al. (2004), we hypothesise that probability of sale for a property is a function of market conditions, property specific features and owner characteristics, i.e.

$$
\operatorname{Pr}\left(\text { SALE }_{i, t}\right)=f\left(\text { MARKET }_{i, t}, \text { ASSET }_{i, t}, \text { OWNER }_{i, t}\right)
$$

Where $\operatorname{Pr}\left(\mathrm{SALE}_{i, t}\right)$ denotes the probability that property $i$ will be sold in period $t$ and MARKET, ASSET and OWNER represent sets of specific variables that capture these groups of factors. The probability of sale cannot be observed directly, but the incidence of a successful sale can be observed. So, for our earlier example, its probability of sale in each year is unknown, but we would observe that it did sell in 2004, 2007 and 2012. Therefore, incidence of sale is modelled to discover which factors, if any, make a property more likely to sell. The incidence of sale is represented as a dichotomous dependent variable that takes the value of 1 if the asset was traded in a period and 0 otherwise. Probit models of the following form are then estimated:

$$
\operatorname{Pr}\left[\mathrm{S}_{i t}=1\right]=\Phi\left[\sum \gamma_{i} \mathrm{X}_{i t}\right]+\varepsilon_{i t}
$$

Where $S_{i, t}$ equals 1 when the property has sold and 0 otherwise, while $X_{i, t}$ are the market, asset and ownership factors that are used to explain the likelihood of sale. In this framework, if the assets that sell within a period possess distinctive attributes, then these should be identified as significant determinants of sale that, by implication, increase the probability of a successful sale for any asset that had them, whether it happened to trade or not. Furthermore, where data span 
several periods, the approach can identify characteristics that lead assets to be sold more often or market conditions that make the sale of all properties more or less likely.

\begin{abstract}
Hence, it is possible to estimate equation (2) either for each individual interval or on a pooled basis whereby the sets of sold and unsold assets for each interval are stacked before estimation. The latter is consistent with the approach taken by Fisher et al. (2004) and allows economic variables to be included that vary over time, but not across cases. In this case, we conducted a pooled estimation for $2003 \mathrm{H} 2$ to $2013 \mathrm{H} 1$, which is shorter than the full period covered by the dataset owing to data limitations. ${ }^{[\mathrm{vi}]}$ We also conducted sub-period estimations to check the robustness of our findings and to discover more about the nature of trading activity in different phases of the real estate cycle.
\end{abstract}

We acknowledge that studying the incidence of sale has drawbacks for analyzing probability of sale. The allocation of a sale to one period or another depends on how the intervals are specified and we do not observe cases where sales were aborted or properties were withdrawn from sale. An alternative approach that is common in residential real estate studies is to analyze time-on-market instead. The modelling of this measure allows inferences to be made about factors that increase the likelihood of sale through the comparison of properties that sell rapidly versus those that take much longer. It is not possible to follow this approach here, though, since time-on-market has not been collected in a systematic fashion for UK commercial real estate, as investment firms do not share (nor do they always collect) this information (see Devaney and Scofield, 2015).

The independent variables used in our analysis were as follows. We created dummy variables to represent the sector and geographical area in which each property was located, and used the log of the floorspace to capture asset size. We wished to include the age and occupancy rate of 
each property as well, but these were unobserved in many cases. We created dummy variables for the different types of owner described above, for different nationality groups, and for cases where the property was held in a joint venture. Meanwhile, market and economic factors are represented by several continuous variables. Summary statistics for the market and economic variables are reported in Table II. Note that the count of observations in this table refers to the number of intervals rather than the number of assets.

We use the RCA/PD UK CPPI (deflated by CPI) to calculate real estate market performance for each interval. However, a potential problem is that market performance could be influenced by trading activity (see Fisher et al. 2009; Ling et al. 2009). Thus, we estimate further models that replace the real estate variable with UK real GDP growth, a broader measure that influences real estate demand and, thus, returns. We expect that stronger real estate returns and stronger economic conditions will increase the pool of potential investors, leading to more transaction activity. We include changes in the Consumer Price Index (CPI) as a further measure of general economic conditions, while government bond yields are added since these yields may influence investor demand and the flow of funds into and out of the commercial real estate sector.

Table II

The spread between corporate bond and government bond yields is used to represent risk in the economy. Moreover, we test a variable that tracks the net amount of real estate lending by UK financial institutions to non-residential real estate. This is sourced from the Bank of England and deflated using $\mathrm{CPI}$. We expect transaction activity to be negatively related to perceptions of risk in the wider economy and positively related to the debt variable, which we adopt as a proxy for the availability of funding to the real estate sector. While we would like to include all of these variables together in our modelling, Panel B of Table II shows that several are highly correlated, 
especially the government bond yield, spread and debt variables. So to avoid multicollinearity, we estimate a variety of models where some of these variables are substituted for one another.

\section{RESULTS}

Estimated coefficients for six panel models are presented in Table III. These relate to sales across the retail, office and industrial sectors. All of the models contain a common set of asset and owner variables, but vary in terms of the market variables that are included. Models 1 to 3 use changes in the RCA/PD CPPI to proxy real estate market conditions while models 4 to 6 employ real GDP growth to represent the performance of the economy. Within these two sets of models, individual models then vary as to whether real government bond yields, spreads or the debt flow variable is included. ${ }^{\text {[vii] }}$

\section{Table III}

It can be seen from Table III that the models are strongly significant in statistical terms, as evidenced by the chi-squared and log likelihood measures. Many individual variables are also statistically significant and there is a high degree of consistency in findings across the models. Pseudo r-squared, while not directly comparable with r-squared from conventional regressions, is very small in all cases. It ranges from $1-2 \%$ for the all property panel models, $2-3 \%$ for office sector panel models, and $1-4 \%$ for the sub period models discussed later. ${ }^{\text {vii }}$ This might reflect that the unsold samples are constructed from a set of sales observed over a fairly short period (in real estate holding period terms). So they omit properties that did not sell at all in the period studied and which might have had more pronounced distinctions in their attributes. Furthermore, there are other asset-specific factors such as occupancy and leasing status that are likely to 
influence probability of sale, but which we could not observe. Despite this, the models indicate a number of interesting influences on transaction activity over this period.

Models 1-3 indicate that sale probability is positively related to capital growth in the real estate market. This corroborates findings in other studies (e.g. Fisher et al., 2004; Guilkey et al., 1989) that trading is pro-cyclical, with higher returns from real estate investments stimulating more transaction activity. Models 4-6 indicate that there is a significant, positive relationship between economic growth, as a key driver of real estate performance, and the likelihood of sale. Inflation is positively related to sale probability, as is the yield on index-linked government bonds. These results are harder to interpret, but higher inflation and lower bond yields corresponded with the recovery in UK commercial real estate markets following the GFC. In line with expectations, as the spread between corporate and government bond yields widened in response to perceptions of risk, probability of sale was reduced. In contrast, as the flow of new debt into commercial real estate rose, the likelihood of transactions also increased. This is likely to reflect that greater debt availability allowed an increased number and range of investors to participate in the real estate market.

Asset characteristics were also important drivers of probability of sale. Office and retail assets were more likely to be traded than the base category of industrial, after controlling for other factors. Assets located in the City and West End areas of Central London were more likely to be sold than assets in the base location, Rest of South East, or indeed anywhere else in the UK. This is in line with market perceptions of higher liquidity for Central London assets. CBD locations in the rest of England and rest of UK were associated with a higher probability of sale relative to the base location. Surprisingly, larger assets in terms of square footage appeared to have an increased probability of sale. This result contrasts with Collett et al. (2003) who found that smaller assets sold more often, but they examined institutional investors in a period when 
these investors consolidated portfolios on a smaller number of high-value assets (see Callender et al. 2007). Our results suggest that the rebalancing away from smaller properties might now be complete, but a positive association with sale probability might also reflect issues with data coverage.

Meanwhile, owner characteristics are found to be important as well. The base group for types of owner is institutions. There are no significant differences in these models between this group and either equity funds or third-party investment management firms. In contrast, private investors, REITs and REOCs are found to be positively associated with probability of sale, as were owners in the user/other group. This is the first time this has been noted, since previous research has not had access to the data necessary to investigate investor motivation by owner type and nationality. We find that only European investors appear to be distinct from UK investors when the whole period is considered. Owners domiciled in European countries are negatively associated with probability of sale, which suggests differences in their preferred holding periods. This could reflect higher transaction and information costs associated with investing from distance, but the same effect is not found for either US investors or investors from the Rest of the World. This suggests a difference in tolerance to illiquidity between investor types and nationalities. We also find a significant and positive association between probability of sale and the use of a joint venture.

\section{Table IV}

Table IV shows results for the office sector. Broadly speaking, many factors that were significant in the models for all sectors remain significant in the office models. Real estate price trends, real GDP growth, real bond yields, spreads and the net flow of debt to commercial real estate all remain significant. Larger properties continue to be positively associated with sale probability 
and similar relationships with location are again evident, with the City and West End of London having positive coefficients, as does the indicator for other UK CBD locations. However, the influence of owner type is diminished as only REOCs are found to be significantly more likely to sell compared to institutions as the base group. For nationality, European owners continue to be negatively associated with probability of sale.

Tables $\mathrm{V}$ and $\mathrm{VI}$ then show results for sub-periods. The sub periods have been defined in terms of two-year windows that correspond with different phases of the UK commercial real estate cycle. $^{[i x]}$ The first period studied is mid-2003 to mid-2005, corresponding with positive growth in real estate prices, while mid-2005 to mid-2007 corresponds with more rapid growth and with higher levels of trading, as shown earlier in Figure 1. After mid-2007, prices then began to drop with the onset of the GFC, a fall that continued through 2008 until a trough was reached around the middle of 2009. Thus, we examine mid-2007 to mid-2009, in particular, to see if asset and ownership factors influencing probability of sale changed while the market was falling. The final two periods then relate to years where recovery in both real estate prices and trading volumes was occurring.

Table V

Table VI

The results in Tables $\mathrm{V}$ and $\mathrm{VI}$ show clear intertemporal differences in the factors that influenced probability of sale. In both cases, there is an increase in the pseudo r-squared for models of the downturn sub-period, which suggests that biases in what transacts become more pronounced in difficult market conditions. While retail and office properties were positively associated with sale probability before the GFC, coefficients for these sectors turned negative and significant in the 
downturn. Larger assets were also positively associated with probability of sale up until the GFC. The switch from a positive to a negative relationship might well reflect changes in the availability of finance needed to facilitate larger deals once market conditions had altered. The coefficients for locations vary through time as well. The City of London appears the most consistent location in terms of being associated with higher sale probability, but the West End of London becomes similarly associated from the downturn onwards. This suggests that Central London submarkets offered the advantage of greater liquidity for real estate investors during more difficult market conditions.

The owner variables suggest changes in the likelihood of selling by different investor types and nationalities over the cycle. During the growth and boom years of 2003 to 2007, equity funds and private investors were positively associated with the probability of sale relative to the base group of institutions. Also worth noting in Table $\mathrm{V}$ is the strong positive coefficient on user/other for the boom period of mid-2005 to mid-2007. In this period, sale and leaseback deals involving transfers of real estate from the owner-occupied sector to the investment market were facilitated by the ready availability of finance. However, in the downturn and its aftermath, ownership by equity funds or private investors lowered the probability of sale for the assets in the sample. In contrast, REITs exhibit a positive and significant coefficient in the all property models from mid2007 onwards. Finally, domestic ownership raised the probability of sale during the downturn, but, outside of this window, it had less influence.

\section{CONCLUSION}

From an extensive dataset of UK commercial real estate sales, we identified which factors most affected probability of sale over the real estate cycle. Identifying these factors is important as it can inform investment strategies and our understanding of how real estate investment markets 
operate. Building on earlier research, we defined the probability of a commercial real estate sale as a function of market, asset and owner characteristics. We considered the effects of attributes such as type, size and location on probability of sale as well as ownership type and nationality, plus a range of economic variables such as real GDP growth and the flow of debt finance. In addition, we analyzed sub-periods to understand how patterns change across the market cycle.

Unlike earlier research, we were able to analyze samples of transactions drawn from all investor types (domestic and international). This was a significant advantage over studies based on data drawn from NCREIF or IPD, which are restricted to samples of domestic institutional investors for the markets being studied. We show that the behavior of non-institutional investors differed from that of institutional investors in this period and, likewise, that foreign investors behaved differently to domestic investors. However, the nature of our dataset meant that we had to infer which assets were held at particular times using information on sales from other points in time, which is a limitation to our analysis.

We found that the types of asset traded in different market conditions varied. For example, office and retail properties were more likely to trade than industrial properties overall and during strong market conditions, but were less likely to sell than industrial assets during the market downturn. Such differences have implications for measuring movements in real estate prices. It suggests that the nature and impact of sample selection biases might vary through time and must be monitored as a result. It also impacts on investor strategies regarding sale timing and portfolio rebalancing. We found that assets located in the City and West End areas of London had a higher probability of sale in the downturn and its aftermath relative to properties in other locations. This suggests that liquidity may be higher here in times of market stress and that liquidity risks in Central London are lower than in other areas. 
This latter finding, in particular, has important implications for commercial real estate investors. For example, it is sometimes assumed that real estate investors in central London are accepting yields that are seemingly discordant with underlying risk due to familiarity bias (Henneberry and Mouzakis, 2014) or information asymmetry, especially in the case of foreign investors. However, our findings suggest that lower yields might be the price of liquidity, most especially in market downturns when falling values dissuaded many investors from entering the market. In these conditions, as was the case during the GFC, City and West End properties were more likely to sell, suggesting a prudent bias among investors for the comparatively higher price / lower yield properties found in these pockets of London.

REITs and REOCs were more likely to sell than UK institutions, and European owners were significantly less likely to sell than UK owners. We expected to see variation in the composition and activity of buyers and sellers at different times, and bias in the selection of assets for sale at different points in the market cycle, but we assumed that all investors would be similarly averse to selling into a rapidly falling market and we did not foresee the preponderance of sales by UKbased investors as compared to their non-local counterparts. Although we control for owner type, among other factors, it may be that pressures on UK retail funds, in particular, and consequent requirements to sell assets to meet redemptions influence this finding. It may also be the case that non-UK investors have paid more for their assets than locals and/or need to amortize the higher transaction (search and information) costs associated with foreign investment, and so are reticent to realize losses by selling during the downturn.

Future research on probability of sale would benefit from further data on unsold assets or from observing sales over a longer period during which more of the stock is likely to have sold. It could also extend the literature on pricing by comparing and correcting for differences in asset selection between institutional and non-institutional or domestic and foreign investors in different 
locations. Another challenge for future research is to further examine the effects of investor national origin by discerning not only the country of registry, but also the location of effective or beneficial ownership, though such an exercise would be complex. The role that intermediaries such as brokers play in the processes of asset selection and pricing in commercial real estate markets is also worthy of further examination.

This paper considers the UK real estate market, but it is likely that many of the findings hold for other major commercial real estate markets. Variation in sale probability over time and across assets has implications for real estate investment management both in terms of asset selection and the ability to rebalance portfolios of assets over the course of the cycle. Furthermore, the results suggest that sample selection may be an issue for commercial real estate price indices around the globe, while they also imply that indices based on a limited group of owners/sellers might be susceptible to further biases when tracking market performance through time. 


\title{
REFERENCES
}

Ametefe, F., Devaney, S. and Marcato, G. (2016), "Liquidity: A Review of Dimensions, Causes, Measures, and Empirical Applications in Real Estate Markets", Journal of Real Estate Literature, Vol 24 No 1, pp. 1-29.

Baroni, M., Barthelemy, F and Mokrane, M. (2007), “Optimal Holding Period for a Real Estate Portfolio", Journal of Property Investment and Finance, Vol 25 No 6, pp. 607-625.

Brown, R. and Geurts, T. (2005), "Private Investor Holding Period", Journal of Real Estate Portfolio Management, Vol 11 No 2, pp. 93-104.

\begin{abstract}
Callender, M., Devaney, S. and Sheahan, A. (2007), Risk Reduction and Diversification in Property Portfolios, Investment Property Forum, London.
\end{abstract}
Cheng, P., Lin, Z. and Yingchun, L. (2010), "Illiquidity, Transaction Cost, and Optimal Holding Period for Real Estate: Theory and Application", Journal of Housing Economics, Vol 19 No 2, pp. 109-118.
Chinloy, P., Hardin, W. and Wu, Z. (2013), "Transaction Frequency and Commercial Property", Journal of Real Estate Finance and Economics, Vol 47 No 4, pp. 640-658.
Collett, D., Lizieri, C. and Ward, C. (2003), "Timing and the Holding Periods of Institutional Real Estate", Real Estate Economics, Vol 31 No 2, pp. 205-222.


Crosby, N., Lizieri, C. and McAllister, P. (2010), "Means, Motive and Opportunity: Disentangling the Effects of Client Influence of Periodic Performance Measurement Appraisals", Journal of Property Research, Vol 27 No 2, pp. 181-201.

Devaney, S. and Martinez Diaz, R. (2011), “Transaction Based Indices for the UK Commercial Real Estate Market: An Exploration Using IPD Transaction Data”, Journal of Property Research, Vol 28 No 4, pp. 269-289.

Devaney, S. and Scofield, D. (2015), "Liquidity and the Drivers of Search, Due Diligence and Transaction Times for UK Commercial Real Estate Investments", Journal of Property Research, Vol 32 No 4, pp. 362-383.

Fisher, J. and Young, M. (2000), "Institutional Property Tenure: Evidence from the NCREIF Database", Journal of Real Estate Portfolio Management, Vol 6 No 4, pp. 327-338.

Fisher, J., Gatzlaff, D., Geltner, D. and Haurin, D. (2003), “Controlling for the Impact of Variable Liquidity in Commercial Real Estate Price Indices", Real Estate Economics, Vol 31 No 2, pp. 269-303.

Fisher, J., Gatzlaff, D., Geltner, D. and Haurin, D. (2004), "An Analysis of the Determinants of Transaction Frequency of Institutional Commercial Real Estate Investment Property", Real Estate Economics, Vol 32 No 2, pp. 239-264.

Fisher, J., Geltner, D. and Pollakowski, H. (2007), “A Quarterly Transactions-based Index of Institutional Real Estate Investment Performance and Movements in Supply and Demand", Journal of Real Estate Finance and Economics, Vol 34 No 1, pp. 5-33. 
Fisher, J., Ling, D. C. and Naranjo, A. (2009), “Institutional Capital Flows and Return Dynamics in Private Commercial Real Estate Markets", Real Estate Economics, Vol 37 No 1, pp. 85-116.

Forbes, J. (2017), A review of real estate fund behaviour following the EU referendum, Report for The Association of Real Estate Funds. John Forbes Consulting LLP.

Gau, G. W. and Wang, K. (1994), “The Tax-Induced Holding Periods of Real Estate Investors: Theory and Empirical Evidence", Journal of Real Estate Finance and Economics, Vol 8 No 1, pp. 71-85.

Gatzlaff, D. H. and Haurin, D. R. (1998), "Sample Selection and Biases in Local House Value Indices", Journal of Urban Economics, Vol 43 No 2, pp. 199-222.

Guilkey, D., Miles, M. and Cole, R. (1989), "The Motivation for Institutional Real Estate Sales and Implications for Asset Class Returns", AREUEA Journal, Vol 17 No 1, pp. 70-86.

Henneberry, J. and Mouzakis, F. (2014), "Familiarity and the Determinants of yields for regional Office Property Investments in the UK", Regional Studies, Vol 48 No 3, pp. 530-546.

Ling, D.C., Marcato, G. and McAllister, P. (2009), "Dynamics of Asset Prices and Transaction Activity in Illiquid Markets: The Case of Private Commercial Real Estate", Journal of Real Estate Finance and Economics, Vol 39 No 3, pp. 359-383.

\author{
Lizieri, C. and Pain, K. (2014), "International Office Investment in Global Cities: The Production \\ of Financial Space and Systemic Risk", Regional Studies, Vol 48 No 3, pp. 439-455.
}


Lizieri, C., Reinert, J. and Baum, A. (2011), Who Owns the City 2011: Change and Global Ownership of City of London Offices, Department of Land Economy: University of Cambridge.

Mitchell, P. (2015), The Size and Structure of the UK Property Market: End-2014 Update, Investment Property Forum, London.

\title{
ACKNOWLEDGMENT
}

The authors thank Real Capital Analytics/Property Data for access to data used in this research. Any errors or omissions are the responsibility of the authors alone.

\section{ENDNOTES}

\begin{abstract}
'Nonetheless, while the sale probability models are not reported, Devaney and Martinez Diaz (2011) suggest that more valuable commercial properties had a lower propensity for sale while variables representing past performance and holding period were not influential.
\end{abstract}

\begin{abstract}
ii According to RCA, the data capture approximately $95 \%$ of all commercial real estate deals above USD 10 million that occurred over the period. Coverage below this threshold will be lower and a complete accounting of all transactions that occurred is not possible from this source. As such, sample selection bias cannot be discounted.
\end{abstract}

\footnotetext{
iii We checked the results that follow by running models with all portfolio deals removed. The results were similar to those that are presented here.
} 
iv We do not use all the investor types recorded by RCA/PD, but we aggregate some into larger categories to ensure that all the types we use are represented in the sold and unsold groups for each window that we analyze.

\begin{abstract}
${ }^{\vee}$ We have checked that our findings were robust to the inclusion or exclusion of cases where the type or nationality of ownership is unknown. The results that include unknown cases were very similar to those presented here and can be obtained from the authors on request.
\end{abstract}

\begin{abstract}
vi We did not analyze 2001 and 2002 since our real estate performance variable was unavailable for these two years. However, transaction records for these years did contribute to the formation of the unsold set of assets in other years.
\end{abstract}

\begin{abstract}
vii We estimated models for all properties and for offices that used time fixed effects in place of the market variables. This was to check on our findings relating to asset and ownership factors. The coefficients on the asset and ownership variables were very similar to those presented in Table III and Table IV, so these models are not reported.
\end{abstract}
viii In comparison, Fisher et al. (2004) achieved values for pseudo r-squared that ranged from 6- $12 \%$.

\footnotetext{
${ }^{\text {ix }}$ As these periods each contain only two intervals in terms of how the sold/unsold set is defined, market variables are excluded from these models. In effect, the sub-period itself controls for the market and economic conditions during that time. However, a time dummy was added for sales in the second half of each window in each case.
} 
Figure I: UK Commercial Real Estate Market Values and Volumes - 2002:4 to 2013:1

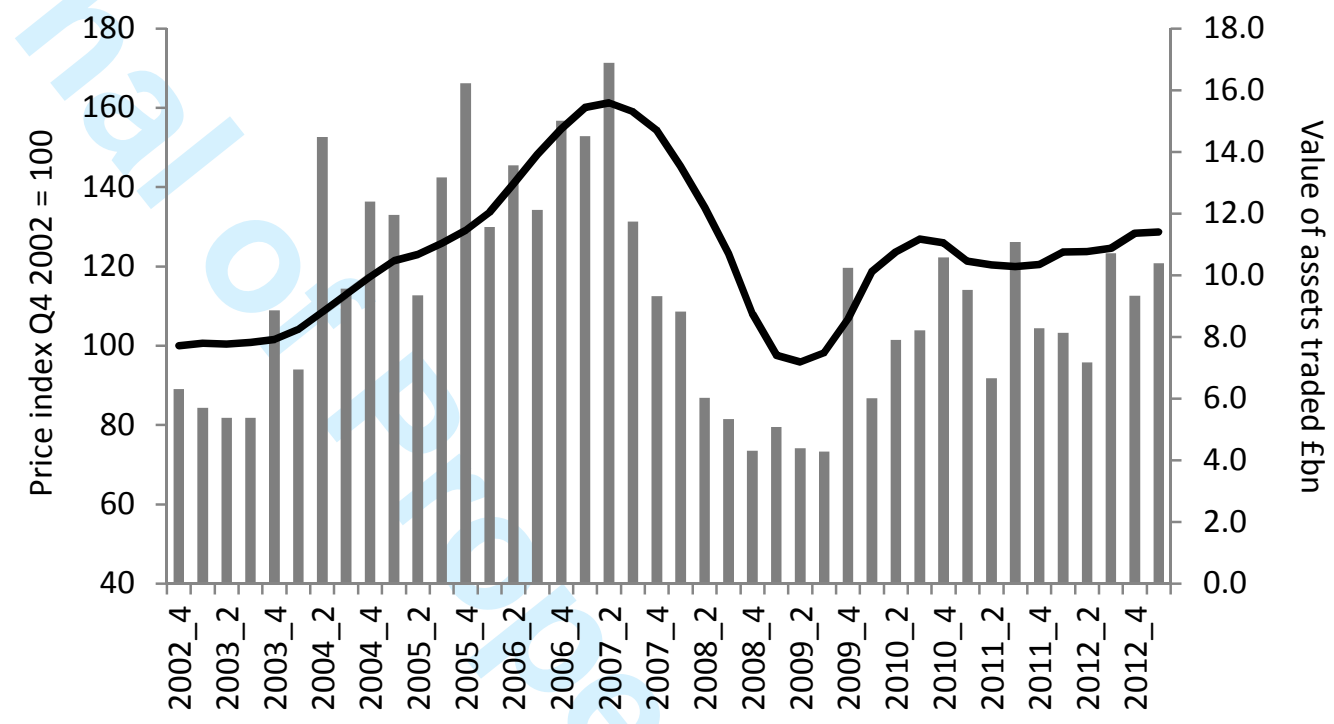

Transactions fbn RCA/PD CPPI 
Figure III: Proportion of deals by type of seller - 2001 to 2013

Figure II: Proportion of deals by type of buyer - 2001 to 2013
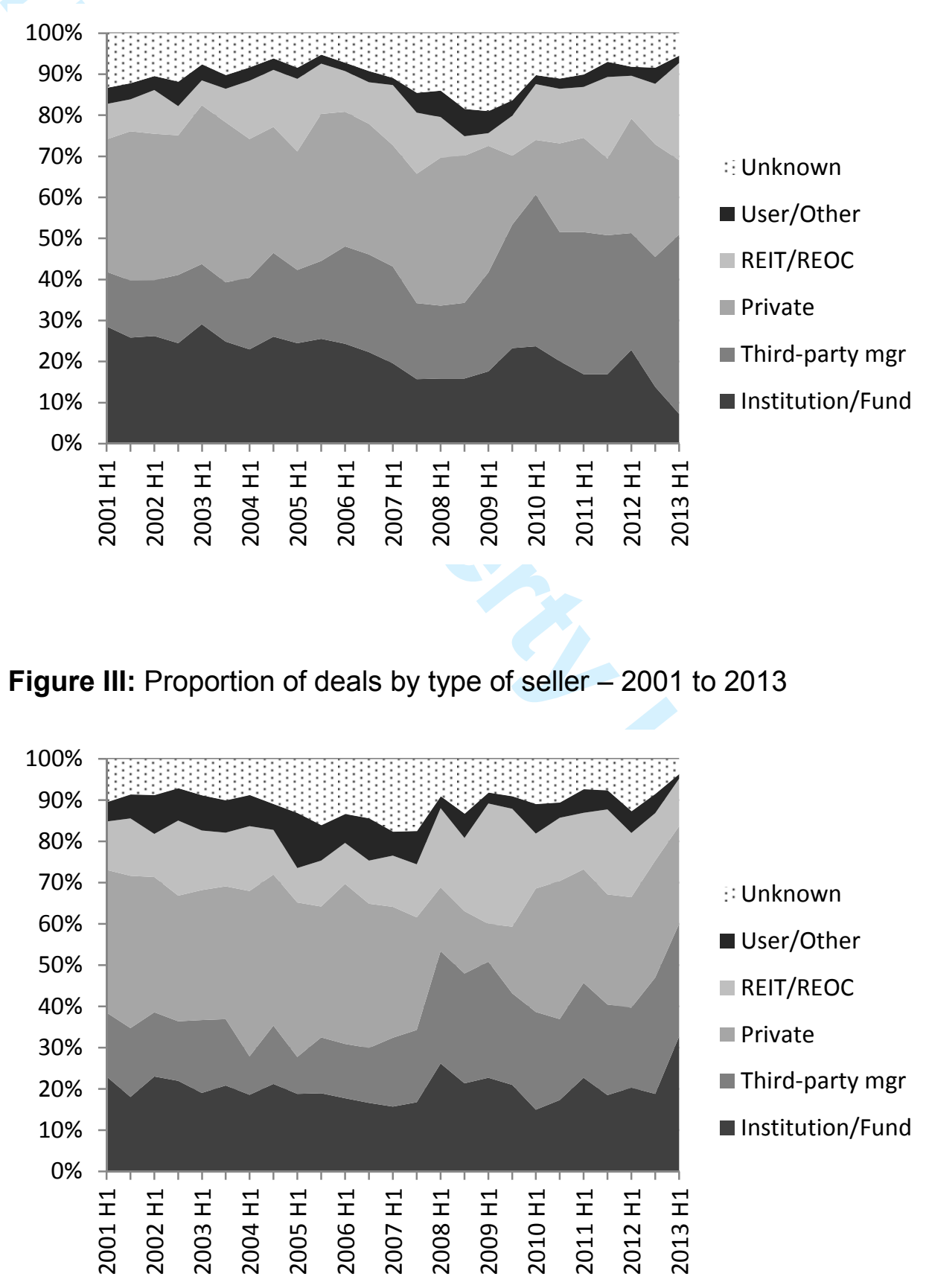
Table I: Distribution of sample of transactions

\begin{tabular}{|c|c|c|c|c|c|}
\hline & Number & $\%$ of total & Value $\mathrm{fbn}$. & $\%$ of total & $\begin{array}{l}\text { Average } \\
\text { price } \mathrm{fm}\end{array}$ \\
\hline \multicolumn{6}{|c|}{ By property type and UK region } \\
\hline Industrial & 2,196 & $18 \%$ & 29.5 & $9 \%$ & 13.4 \\
\hline Office & 5,737 & $47 \%$ & 171.2 & $54 \%$ & 29.8 \\
\hline Retail & 4,176 & $34 \%$ & 115.4 & $37 \%$ & 27.6 \\
\hline Central London & 2,569 & $21 \%$ & 108.8 & $34 \%$ & 42.4 \\
\hline Rest of London & 1,686 & $14 \%$ & 53.3 & $17 \%$ & 31.6 \\
\hline Rest of South East & 1,408 & $12 \%$ & 26.2 & $8 \%$ & 18.6 \\
\hline Rest of England & 4,958 & $41 \%$ & 101.2 & $32 \%$ & 20.4 \\
\hline Other UK & 1,488 & $12 \%$ & 26.5 & $8 \%$ & 17.8 \\
\hline CBD & 6,089 & $50 \%$ & 204.8 & $65 \%$ & 33.6 \\
\hline Non-CBD & 6,020 & $50 \%$ & 111.2 & $35 \%$ & 18.5 \\
\hline \multicolumn{6}{|c|}{ By seller type and nationality } \\
\hline Institution & 1,614 & $13 \%$ & 56.3 & $18 \%$ & 34.9 \\
\hline Equity fund & 756 & $6 \%$ & 28.9 & $9 \%$ & 38.2 \\
\hline Third-party manager & 2,140 & $18 \%$ & 52.9 & $17 \%$ & 24.7 \\
\hline Private investor & 3,676 & $30 \%$ & 76.5 & $24 \%$ & 20.8 \\
\hline REIT & 997 & $8 \%$ & 43.0 & $14 \%$ & 43.2 \\
\hline REOC & 726 & $6 \%$ & 25.2 & $8 \%$ & 34.7 \\
\hline User/other & 822 & $7 \%$ & 15.7 & $5 \%$ & 19.1 \\
\hline Type unknown & 1,378 & $11 \%$ & 17.5 & $6 \%$ & 12.7 \\
\hline United Kingdom & 8,009 & $66 \%$ & 218.2 & $69 \%$ & 27.2 \\
\hline European nation & 926 & $8 \%$ & 30.1 & $10 \%$ & 32.5 \\
\hline United States & 756 & $6 \%$ & 26.6 & $8 \%$ & 35.2 \\
\hline Rest of World & 495 & $4 \%$ & 19.7 & $6 \%$ & 39.8 \\
\hline Nation unknown & 1,923 & $16 \%$ & 21.5 & $7 \%$ & 11.2 \\
\hline \multicolumn{6}{|c|}{ Held in joint venture or not } \\
\hline Single owner & 11,165 & $92 \%$ & 274.8 & $87 \%$ & 24.6 \\
\hline Joint venture & 944 & $8 \%$ & 41.2 & $13 \%$ & 43.6 \\
\hline Total & 12,109 & $100 \%$ & 316.0 & $100 \%$ & 26.1 \\
\hline
\end{tabular}


Table II: Overview of time-series variables - 2003/04 to 2012/13 inclusive

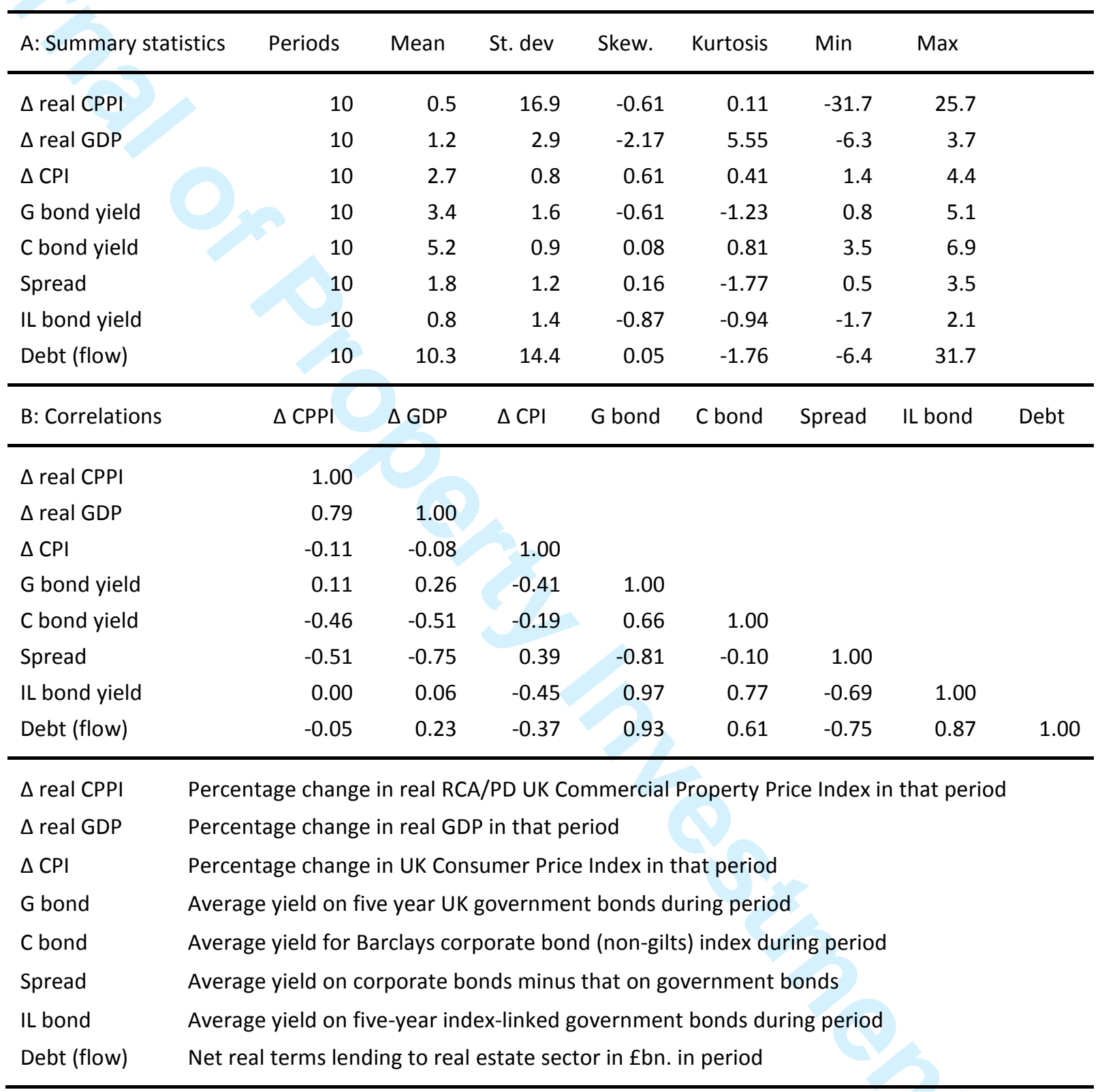


Table III: Probit models of sale probability - all sectors

\begin{tabular}{|c|c|c|c|c|c|c|c|c|c|c|c|c|}
\hline & $(1)$ & & $(2)$ & & (3) & & $(4)$ & & (5) & & $(6)$ & \\
\hline Constant & -1.554 & $* * *$ & -1.315 & $* * *$ & -1.621 & $* * *$ & -1.584 & $* * *$ & -1.329 & $* * *$ & -1.581 & $* * *$ \\
\hline Ln floorspace & 0.019 & $* * *$ & 0.019 & $* * *$ & 0.020 & $* * *$ & 0.019 & $* * *$ & 0.019 & $* * *$ & 0.020 & $* * *$ \\
\hline Office asset & 0.038 & $* *$ & 0.037 & $* *$ & 0.037 & $* *$ & 0.037 & $* *$ & 0.037 & $* *$ & 0.037 & $* *$ \\
\hline Retail asset & 0.052 & $* * *$ & 0.051 & $* * *$ & 0.053 & $* * *$ & 0.051 & $* * *$ & 0.051 & $* * *$ & 0.051 & $* * *$ \\
\hline City of London & 0.186 & $* * *$ & 0.185 & $* * *$ & 0.186 & $* * *$ & 0.185 & $* * *$ & 0.185 & $* * *$ & 0.185 & $* * *$ \\
\hline West End London & 0.110 & $* * *$ & 0.110 & $* * *$ & 0.111 & $* * *$ & 0.109 & $* * *$ & 0.109 & $* * *$ & 0.109 & $* * *$ \\
\hline Rest of London & 0.007 & & 0.006 & & 0.007 & & 0.005 & & 0.005 & & 0.005 & \\
\hline Rest of Eng CBD & 0.047 & $* * *$ & 0.047 & $* * *$ & 0.046 & $* *$ & 0.047 & $* *$ & 0.047 & $* * *$ & 0.046 & $* *$ \\
\hline Rest of Eng non-CBD & 0.027 & & 0.027 & & 0.026 & & 0.026 & & 0.026 & & 0.026 & \\
\hline Other UK CBD & 0.043 & * & 0.044 & $*$ & 0.044 & $*$ & 0.043 & $*$ & 0.043 & $*$ & 0.043 & $*$ \\
\hline Other UK non-CBD & 0.034 & & 0.034 & & 0.033 & & 0.034 & & 0.034 & & 0.033 & \\
\hline Equity fund & -0.014 & & -0.013 & & -0.013 & & -0.014 & & -0.014 & & -0.015 & \\
\hline Third party mgr & 0.013 & & 0.015 & & 0.015 & & 0.014 & & 0.014 & & 0.013 & \\
\hline Private investor & 0.048 & $*$ & 0.048 & * & 0.050 & $* *$ & 0.048 & * & 0.049 & * & 0.050 & $* *$ \\
\hline REIT & 0.095 & $* *$ & 0.099 & $* * *$ & 0.095 & $* *$ & 0.099 & $* * *$ & 0.099 & $* * *$ & 0.099 & $* * *$ \\
\hline REOC & 0.186 & $* * *$ & 0.187 & $* * *$ & 0.186 & $* * *$ & 0.186 & $* * *$ & 0.187 & $* * *$ & 0.187 & $* * *$ \\
\hline User/Other & 0.202 & $* * *$ & 0.197 & $* * *$ & 0.200 & $* * *$ & 0.198 & $* * *$ & 0.197 & $* * *$ & 0.200 & $* * *$ \\
\hline European owner & -0.145 & $* * *$ & -0.141 & $* * *$ & -0.143 & $* * *$ & -0.140 & $* * *$ & -0.140 & $* * *$ & -0.140 & $* * *$ \\
\hline US owner & -0.008 & & -0.007 & & -0.006 & & -0.007 & & -0.006 & & -0.006 & \\
\hline Rest of world & -0.053 & & -0.050 & & -0.051 & & -0.050 & & -0.049 & & -0.051 & \\
\hline Joint venture & 0.081 & $*$ & 0.083 & $*$ & 0.084 & $*$ & 0.083 & * & 0.083 & $*$ & 0.084 & $* *$ \\
\hline Inflation rate & 0.018 & & 0.029 & $* *$ & 0.026 & $*$ & 0.012 & & 0.022 & & 0.005 & \\
\hline$\Delta$ real CPPI & 0.007 & $* * *$ & 0.003 & $* * *$ & 0.007 & $* * *$ & - & & - & & - & \\
\hline$\Delta$ real GDP & - & & - & & - & & 0.047 & $* * *$ & 0.015 & $* *$ & 0.042 & $* * *$ \\
\hline IL bond yield & 0.066 & $* * *$ & - & & - & & 0.055 & $* * *$ & - & & - & \\
\hline Spread & - & & -0.119 & $* * *$ & - & & & & -0.110 & $* * *$ & - & \\
\hline Debt (flow) & - & & - & & 0.009 & $* * *$ & - & & - & & 0.006 & $* * *$ \\
\hline Observations & 59,808 & & 59,808 & & 59,808 & & 59,808 & & 59,808 & & 59,808 & \\
\hline $\operatorname{LR} \times 2$ & 398.9 & & 452.3 & & 460.1 & & 454.4 & & 452.2 & & 456.1 & \\
\hline Probability $>x 2$ & 0 & & 0 & & 0 & & 0 & & 0 & & 0 & \\
\hline Log likelihood & -20066 & & -20016 & & -20002 & & -20031 & & -20024 & & -20019 & \\
\hline Pseudo $R^{2}$ & $1.42 \%$ & & $1.67 \%$ & & $1.74 \%$ & & $1.60 \%$ & & $1.63 \%$ & & $1.66 \%$ & \\
\hline
\end{tabular}

Notes: ${ }^{* * *},{ }^{* *}$ and ${ }^{*}$ denote $1 \%, 5 \%$ and $10 \%$ significance levels, respectively. Dependent variable equals 1 if the asset is sold and 0 if it is held in the period concerned. The omitted categories for each set of dummy variables are as follows: sector - industrial; location - Rest of South East; owner type - Institution; owner nationality - UK; joint venture - no. The number of observations reflects that it is a stacked panel. Further details on how the sold and held assets are identified for each period are given in the main text. 
Table IV: Probit models of sale probability - offices

\begin{tabular}{|c|c|c|c|c|c|c|c|c|c|c|c|c|}
\hline r & (1) & & $(2)$ & & (3) & & (4) & & (5) & & (6) & \\
\hline Constant & -1.499 & $* * *$ & -1.221 & $* * *$ & -1.580 & $* * *$ & -1.544 & $* * *$ & -1.233 & $* * *$ & -1.550 & $* * *$ \\
\hline Ln floorspace & 0.038 & $* * *$ & 0.038 & $* * *$ & 0.038 & $* * *$ & 0.038 & $* * *$ & 0.038 & $* * *$ & 0.039 & $* * *$ \\
\hline City of London & 0.191 & $* * *$ & 0.190 & $* * *$ & 0.191 & $* * *$ & 0.189 & $* * *$ & 0.189 & $* * *$ & 0.189 & $* * *$ \\
\hline West End London & 0.124 & $* * *$ & 0.124 & $* * *$ & 0.125 & $* * *$ & 0.123 & $* * *$ & 0.123 & $* * *$ & 0.123 & $* * *$ \\
\hline Rest of London & 0.016 & & 0.014 & & 0.015 & & 0.013 & & 0.013 & & 0.012 & \\
\hline Rest of Eng CBD & 0.042 & & 0.043 & & 0.043 & & 0.043 & & 0.043 & & 0.042 & \\
\hline Rest of Eng non-CBD & -0.001 & & -0.002 & & -0.003 & & -0.002 & & -0.002 & & -0.004 & \\
\hline Other UK CBD & 0.071 & $* *$ & 0.072 & $* *$ & 0.071 & $* *$ & 0.071 & $* *$ & 0.071 & $* *$ & 0.070 & $* *$ \\
\hline Other UK non-CBD & 0.035 & & 0.035 & & 0.034 & & 0.034 & & 0.033 & & 0.030 & \\
\hline Equity fund & -0.019 & & -0.017 & & -0.016 & & -0.018 & & -0.017 & & -0.018 & \\
\hline Third party mgr & 0.009 & & 0.013 & & 0.013 & & 0.012 & & 0.013 & & 0.012 & \\
\hline Private investor & 0.014 & & 0.014 & & 0.016 & & 0.015 & & 0.015 & & 0.017 & \\
\hline REIT & 0.056 & & 0.062 & & 0.059 & & 0.061 & & 0.062 & & 0.062 & \\
\hline REOC & 0.191 & $* * *$ & 0.195 & $* * *$ & 0.198 & $* * *$ & 0.192 & $* * *$ & 0.195 & $* * *$ & 0.195 & $* * *$ \\
\hline User/Other & -0.007 & & -0.008 & & -0.005 & & -0.008 & & -0.008 & & -0.005 & \\
\hline European owner & -0.166 & $* * *$ & -0.162 & $* * *$ & -0.162 & $* * *$ & -0.160 & $* * *$ & -0.160 & $* * *$ & -0.160 & $* * *$ \\
\hline US owner & -0.043 & & -0.040 & & -0.039 & & -0.041 & & -0.040 & & -0.041 & \\
\hline Rest of world & -0.026 & & -0.023 & & -0.025 & & -0.023 & & -0.022 & & -0.024 & \\
\hline Joint venture & 0.059 & & 0.062 & & 0.063 & & 0.061 & & 0.062 & & 0.063 & \\
\hline Inflation rate & -0.013 & & -0.001 & & -0.005 & & -0.015 & & -0.003 & & -0.022 & \\
\hline$\Delta$ real CPPI & 0.009 & $* * *$ & 0.003 & $* *$ & 0.009 & $* * *$ & - & & - & & - & \\
\hline$\Delta$ real GDP & - & & - & & & & 0.053 & $* * *$ & 0.014 & & 0.047 & $* * *$ \\
\hline IL bond yield & 0.080 & $* * *$ & - & & - & & 0.067 & $* * *$ & - & & & - \\
\hline Spread & - & & -0.137 & $* * *$ & - & & & & -0.134 & $* * *$ & - & - \\
\hline Debt (flow) & - & & - & & 0.011 & $* * *$ & - & & - & & 0.008 & $3 * * *$ \\
\hline Observations & 27,595 & & 27,595 & & 27,595 & & 27,595 & & 27,595 & & 27,595 & \\
\hline $\operatorname{LR} \times 2$ & 316.6 & & 349.3 & & 373.8 & & 352.3 & & 349.7 & & 358.5 & \\
\hline Probability $>x 2$ & 0 & & 0 & & 0 & & 0 & & 0 & & 0 & \\
\hline Log likelihood & -9338 & & -9315 & & -9293 & & -9326 & & -9321 & & -9311 & \\
\hline Pseudo $\mathrm{R}^{2}$ & $1.99 \%$ & & $2.23 \%$ & & $2.46 \%$ & & $2.12 \%$ & & $2.17 \%$ & & $2.27 \%$ & \\
\hline
\end{tabular}

Notes: ${ }^{* *}, * *$ and $*$ denote $1 \%, 5 \%$ and $10 \%$ significance levels, respectively. Dependent variable equals 1 if the asset is sold and 0 if it is held in the period concerned. The omitted categories for each set of dummy variables are as follows: location - Rest of South East; owner type Institution; owner nationality - UK; joint venture - no. The number of observations reflects that it is a stacked panel. Further details on how the sold and held assets are identified for each period are given in the main text. 
Table V: Regressions for sub-periods - all sectors

\begin{tabular}{|c|c|c|c|c|c|c|c|c|}
\hline \multirow[b]{2}{*}{ Constant } & \multicolumn{2}{|c|}{$\begin{array}{l}\text { GROWTH } \\
\text { Mid-2003 to } \\
\text { Mid-2005 }\end{array}$} & $\begin{array}{c}\text { BоoM } \\
\text { Mid-2005 to } \\
\text { Mid-2007 }\end{array}$ & \multicolumn{2}{|c|}{$\begin{array}{l}\text { DOWNTURN } \\
\text { Mid-2007 to } \\
\text { Mid-2009 }\end{array}$} & $\begin{array}{l}\text { RECOVERY } \\
\text { Mid-2009 to } \\
\text { Mid-2011 }\end{array}$ & \multicolumn{2}{|c|}{$\begin{array}{l}\text { GROWTH } \\
\text { Mid-2011 to } \\
\text { Mid-2013 }\end{array}$} \\
\hline & -2.153 & $* * *$ & $-1.347 * * *$ & -0.882 & $* * *$ & $-1.494 * * *$ & -1.120 & $* * *$ \\
\hline Ln floorspace & 0.137 & $* * *$ & $0.031 *$ & -0.061 & $* * *$ & 0.033 & -0.063 & $* *$ \\
\hline Office asset & 0.327 & $* * *$ & $0.131 * * *$ & -0.117 & $* *$ & -0.109 & -0.108 & \\
\hline Retail asset & 0.332 & $* * *$ & 0.016 & -0.191 & $* * *$ & 0.102 & -0.002 & \\
\hline City of London & 0.079 & & $0.170 * *$ & 0.201 & $* *$ & $0.269 * *$ & 0.218 & $* *$ \\
\hline West End London & -0.024 & & -0.026 & 0.217 & $* * *$ & $0.249 * * *$ & 0.199 & $* * *$ \\
\hline Rest of London & -0.021 & & -0.064 & 0.087 & & 0.057 & -0.016 & \\
\hline Rest of Eng CBD & -0.035 & & 0.026 & 0.129 & $*$ & $0.108 *$ & 0.015 & \\
\hline Rest of Eng non-CBD & -0.051 & & 0.048 & 0.124 & $* *$ & 0.018 & -0.035 & \\
\hline Other UK CBD & -0.065 & & 0.066 & 0.121 & & 0.111 & -0.030 & \\
\hline Other UK non-CBD & -0.058 & & 0.006 & 0.214 & $* *$ & 0.022 & 0.000 & \\
\hline Equity fund & 0.164 & $* *$ & 0.119 & -0.098 & & $-0.310 * * *$ & -0.024 & \\
\hline Third party mgr & -0.058 & & 0.023 & 0.040 & & -0.011 & 0.032 & \\
\hline Private investor & 0.228 & $* * *$ & $0.311 * * *$ & -0.331 & $* * *$ & $-0.119 *$ & -0.058 & \\
\hline REIT & -0.133 & $*$ & 0.004 & 0.184 & $* *$ & $0.243 * *$ & 0.186 & \\
\hline REOC & 0.307 & $* * *$ & 0.060 & 0.183 & & 0.164 & 0.267 & \\
\hline User/Other & 0.202 & * & $0.511 * * *$ & 0.041 & & -0.042 & 0.037 & \\
\hline European owner & -0.193 & $* * *$ & $-0.216 * * *$ & -0.317 & $* * *$ & -0.113 & 0.086 & \\
\hline US owner & 0.083 & & 0.037 & -0.208 & $* * *$ & 0.064 & 0.000 & \\
\hline Rest of world & -0.037 & & 0.054 & -0.468 & $* * *$ & -0.150 & 0.159 & \\
\hline Joint venture & -0.042 & & -0.061 & -0.086 & & 0.104 & 0.434 & $* * *$ \\
\hline Time FE & YES & & YES & YES & & YES & YES & \\
\hline No of observations & 11,394 & & 11,708 & 12,096 & & 12,211 & 12,399 & \\
\hline LR $\times 2$ & 157.0 & & 152.5 & 212.6 & & 66.7 & 76.2 & \\
\hline Probability $>x 2$ & 0.0 & & 0.0 & 0.0 & & 0.0 & 0.0 & \\
\hline Log likelihood & -4061.8 & & -5023.1 & -3284.5 & & -3665.3 & -3579.2 & \\
\hline Pseudo $\mathrm{R}^{2}$ & $2.55 \%$ & & $2.00 \%$ & $4.20 \%$ & & $1.77 \%$ & $2.22 \%$ & \\
\hline
\end{tabular}

Notes: ${ }^{* *},{ }^{* *}$ and ${ }^{*}$ denote $1 \%, 5 \%$ and $10 \%$ significance levels, respectively. Dependent variable equals 1 if the asset is sold and 0 if it is held in the period concerned. The omitted categories for each set of dummy variables are as follows: sector - industrial; location - Rest of South East; owner type - Institution; owner nationality - UK; joint venture - no. 
Table VI: Regressions for sub-periods - office sector

\begin{tabular}{|c|c|c|c|c|c|}
\hline & $\begin{array}{l}\text { GROWTH } \\
\text { Mid-2003 to } \\
\text { Mid-2005 }\end{array}$ & $\begin{array}{c}\text { Boom } \\
\text { Mid-2005 to } \\
\text { Mid-2007 }\end{array}$ & $\begin{array}{l}\text { DOWNTURN } \\
\text { Mid-2007 to } \\
\text { Mid-2009 }\end{array}$ & $\begin{array}{l}\text { ReCOVERY } \\
\text { Mid-2009 to } \\
\text { Mid-2011 }\end{array}$ & $\begin{array}{l}\text { GROWTH } \\
\text { Mid-2011 to } \\
\text { Mid-2013 }\end{array}$ \\
\hline Constant & $-1.774 * * *$ & $-1.251 * * *$ & $-1.075 * * *$ & $-1.665 * * *$ & $-1.353 * * *$ \\
\hline Ln floorspace & $0.099 * * *$ & $0.067 * * *$ & -0.023 & $0.086 * *$ & -0.048 \\
\hline City of London & 0.140 & $0.132 *$ & $0.222 * *$ & 0.198 & $0.292 * * *$ \\
\hline West End London & 0.062 & -0.042 & $0.239 * *$ & $0.225^{* *}$ & $0.229 * *$ \\
\hline Rest of London & 0.105 & -0.121 & 0.154 & -0.044 & 0.022 \\
\hline Rest of Eng CBD & 0.048 & -0.016 & 0.102 & 0.060 & 0.036 \\
\hline Rest of Eng non-CBD & -0.108 & -0.017 & 0.098 & -0.135 & 0.108 \\
\hline Other UK CBD & 0.088 & 0.015 & 0.129 & 0.019 & 0.127 \\
\hline Other UK non-CBD & $-0.473 * *$ & -0.101 & $0.512 * * *$ & -0.519 & 0.377 \\
\hline Equity fund & $0.275 * * *$ & 0.137 & $-0.208 *$ & $-0.362 * * *$ & -0.039 \\
\hline Third party mgr & 0.077 & -0.046 & -0.020 & -0.012 & 0.049 \\
\hline Private investor & $0.237 * * *$ & $0.241 * * *$ & $-0.341 * * *$ & $-0.234 * * *$ & -0.037 \\
\hline REIT & -0.050 & -0.125 & 0.066 & 0.145 & $0.258 *$ \\
\hline REOC & $0.429 * * *$ & 0.029 & -0.089 & 0.044 & $0.432 *$ \\
\hline User/Other & 0.157 & 0.149 & -0.182 & -0.097 & -0.250 \\
\hline European owner & $-0.222 * * *$ & $-0.134 *$ & $-0.345 * * *$ & -0.149 & 0.000 \\
\hline US owner & 0.125 & 0.015 & $-0.238 * *$ & -0.055 & -0.008 \\
\hline Rest of world & -0.026 & -0.008 & $-0.414 * * *$ & -0.230 & 0.266 \\
\hline Joint venture & 0.008 & -0.043 & -0.100 & 0.116 & $0.297 * *$ \\
\hline Time FE & YES & YES & YES & YES & YES \\
\hline No of observations & 5,203 & 5,362 & 5,615 & 5,666 & 5,749 \\
\hline $\operatorname{LR} \chi 2$ & 62.1 & 59.3 & 116.3 & 46.8 & 54.2 \\
\hline Probability $>x 2$ & 0.0 & 0.0 & 0.0 & 0.0 & 0.0 \\
\hline Log likelihood & -1935.1 & -2442.4 & -1540.3 & -1551.0 & -1650.5 \\
\hline Pseudo $\mathrm{R}^{2}$ & $2.03 \%$ & $1.32 \%$ & $4.38 \%$ & $2.81 \%$ & $3.10 \%$ \\
\hline
\end{tabular}

Notes: $* * * * *$ and $*$ denote $1 \%, 5 \%$ and $10 \%$ significance levels, respectively. Dependent variable equals 1 if the asset is sold and 0 if it is held in the period concerned. The omitted categories for each set of dummy variables are as follows: location - Rest of South East; owner type Institution; owner nationality - UK; joint venture - no. 